\title{
Construction of the Dispositions of Institutional habitus in the Academic Field ${ }^{1}$
}

\author{
Luciana Massi (Corresponding autor) \\ Department of Didatics, Faculty of Sciences and Letters of Araraquara, Universidade \\ Estadual Paulista, Sao Paulo, Brazil \\ Rodovia Araraquara-Jaú, km 1 CEP 14.800-901 Araraquara \\ Tel: 55-16-3334-6244Ｅ-mail: lu.massi.ana@gmail.com
}

\begin{abstract}
Alberto Villani
Applied Physics Department, Institute of Physics, University of Sao Paulo, Sao Paulo, Brazil
\end{abstract}

Rua do Matão Travessa R Nr.187 CEP 05508-090 Cidade Universitária

Tel: 55-11-3091-6860Ｅ-mail: avillani@usp.br

Received: March 9, 2014 Accepted: April 4, 2014 Published: May 16, 2014

doi:10.5296/ire.v2i2.5263 URL: http://dx.doi.org/10.5296/ire.v2i2.5263

\begin{abstract}
This paper describes the main phases of development of an Institute of Chemistry in relation with national policy from the academic field. Its history begins with a proposal to meet the demand for chemistry teacher education and goes on to become a major center for research, education and extension. Throughout its 50 years of history, the Institution has faced numerous challenges by adopting strategies that have established and revealed its institutional habitus. To this end, we use some of René Kaës's concepts about the development of groups and institutions, highlighting mainly the origins, expectations and covenants that underpinned its foundation, and the entire process of its expansion and institutionalization. Our main focus, also interpreted based on the theory of Pierre Bourdieu and followers, is the establishment of its institutional habitus, i.e., how it interprets and organizes its institutional teaching, research and extension activities within the context of the academic field. The peculiarity of the
\end{abstract}

\footnotetext{
${ }^{1}$ Some excerpts of this paper were presented at the $17^{\text {th }}$ National Meeting of Research in Science Education and submitted for presentation at the $35^{\text {th }}$ Annual Meeting of ANPED and at the $14^{\text {th }}$ Annual International Conference on Education.
} 
process has been the mismatch between internal and external pressures. Even though presenting the results of a case study, in general, our methodology can improve the understanding of institution's development in relation with educational policy.

Keywords: institutional habitus, academic field, chemistry teaching, teacher education

\section{Introduction}

Issues in teacher education have been the subject of numerous studies in the field of Science Education, and more generally in the field of Education. The explicit or implicit goal of all these studies is to outline the characteristics of an effective education, and eventually, the conditions that make it possible. In the specific case of teacher education in Brazil, an important point, and one that strongly influences its performance, is the entry condition of students applying to become teachers, in terms of their social and cultural origins, their preferences, their customs, and their affective and cognitive difficulties. However, the history of the institution also seems to have a strong influence on the process of transformation of future teachers, due to both the specific competence of the teachers who work in it and the traditions and values that inform the theoretical and practical choices that are made. Unfortunately, surveys of the explicit and implicit conditions of the educational institution have been neglected in researches about initial teacher education. It seems to us that knowledge about the history and habitus of the educational institution enables one to focus on its needs and limits and to adjust ideal educational projects to its real institutional context. This seems more relevant in the case of science teacher education, because there are considerable differences in the research-related traditions of educational institutions.

In this paper, aiming to demonstrate our institutional analysis, we present the history of the Institute of Chemistry (IQ) of Araraquara, of the São Paulo State University "Julio de Mesquita Filho" (UNESP), a nationally and internationally recognized Institution. To this end, we use some of René Kaës's (1997) concepts about the development of groups and institutions, highlighting mainly the origins, expectations and covenants that underpinned its foundation, and the entire process of its expansion and institutionalization. Our main focus, also interpreted based on the theory of Pierre Bourdieu and followers, is the establishment of its institutional habitus, i.e., how it interprets and organizes its institutional teaching, research and extension activities within the context of the academic field. This will enable us to interpret the Institution's relationship with Teacher Training (hereinafter referred to as Licentiation or Licentiate Course) and bring to light the mechanisms that implicitly made Chemistry teacher education an important element in the dynamics of the Institution. This work is part of a larger study that aims to analyze the educational histories of the Institution's undergraduates and their relationship with the institutional context.

\section{Theoretical Framework and Research Methodology}

In the genesis and transformation of the history of an institution, Kaës highlights three organizing moments characterized by the increasing complexity of the particular courses: the original, ideological and mythopoetic moments. Each of these moments involves group psychic organizers, which tend to reduce the diversity of the elements involved in the 
economy and dynamics of institutional relationships. We will attempt to interpret the history of our institution in accordance with this disposition, highlighting the characteristics of each moment. The legitimacy of our interpretation can be assessed basedl on the empirical evidence presented.

As mentioned earlier, our intention is to understand how, over time, a set of values and attitudes were created that strongly influence the way its leaders, faculty and staff deal with students working on their Licentiateship and Bachelor's degrees. In the literature, the shift in correlation between the institution and its agents is being studied under the name “institutional habitus" created from Bourdieu's (1983a) concept of habitus. Briefly, habitus refers to a system of rules, ways of perceiving, feeling, doing, and thinking that lead us to act a certain way in a given circumstance (Bourdieu, 1983a). Considering Lahire's (2002), Reay et al. (2001) and Thomas (2002) analysis, our notion of "institutional habitus" consists in retrieving the values and practices the institution has used throughout its history to overcome the challenges it has faced in achieving its institutionalization and legitimization in the academic field.

Another important concept tied to the institutional habitus is that of the academic field, referring to the general concept of field, i.e., "a microcosm included in the macrocosm constituted by social space" (Lahire, 2002, p. 47). According to Bourdieu (1983b), the field appears as a structured space of positions that has universal and invariant operating laws, is defined by specific objects of dispute and interests, is structured through specific accumulated capital, and has at play the struggles over the monopoly of legitimate violence (specific authority), which encompasses strategies of conservation through which it holds higher specific capital, and strategies of subversion by the holders of lesser capital, usually the newcomers.

Our reconstruction of the history of this institution is based on information from various sources. We started by consulting a few specific publications on the subject of UNESP (Vaidergorn, 1995; Massabni et al., 1999, 2003; Corrêa, 2006; Furlan et al., 2008), after which we were given access to interviews with faculty members, granted by the center for documentation and memory of the Institution in question. Finally, we obtained most part of the information from interviews conducted with eight professors who participated in the early stages of development of the course, six professors currently participating in the Institution, and one employee responsible for academic administration, who plays an important role in the Institution. Many of the interviewed professors have acted as heads of department, directors and deputy directors in the institution, and most of them also earned their undergraduate and graduate degrees from the institution.

In the construction of the institution's history, the fundamental framework considered was Kaës's theoretical disposition, which guided the search for the key moments and impasses encountered by the institution, as well as the recognition of the intermediaries that enabled it to overcome its difficulties. We consider that the disposition used here was significantly helpful in the questioning and interpreting the collected data, especially those concerning the initial phase and the process of institutionalization. On the other hand, we felt that in the 
mythopoetic phase there was an expansion of the narcissistic contract and of initial negational pacts, at least on the part of the institution's directors, and that this type of development is not always a characteristic of Kaës's model. However, the references of Bourdieu and his followers helped us to seek in the available data and particularly among the intermediaries for evidence pointing to the origin and establishment of the institutional habitus.

\section{Background and Context of the Creation of the Chemistry Course}

The University of São Paulo (USP) was founded in Brazil in 1934, and was the country's first university dedicated to teaching, research and community work. Due to its primacy and location in the capital of the country's wealthiest state, USP was considered a model for other institutions of higher education, like the Isolated Institutes of Higher Education in the State of São Paulo (Liesesps) (Vaidergorn, 1995; Corrêa, 2006). They were schools of higher education not linked to any university, created in the 1950s to offer a higher education option for cities in the inland of the state of São Paulo. The creation of the Liesesps was motivated, among other factors, by the development of cities, the study conditions of girls inland, the settlement of licentiates in the interior, and the absorption of professors coming from USP (Vaidergorn, 1995; Corrêa, 2006). For the government the situation was controversial because, on the one hand, there was pressure from local communities favorable to the expansion of public higher education and, on the other, there was the resistance of USP, which feared a loss of quality due to the lack of a competent critical mass to support this expansion.

Between January and September 1957, laws were approved to create 6 FPSLs, including the Faculty of Philosophy, Sciences and Letters of Araraquara (FPSLA) (Vaidergorn, 1995). This institution began working in 1959 when Paulo Guimarães da Fonseca, a professor of Chemistry at USP was invited to become its first director (Furlan et al., 2008). Besides the claimed region's demand for chemistry professors that motivates the course creation, it was decided to offer the licentiate and bachelor's courses in Chemistry jointly, and to split them up in the $4^{\text {th }}$ year; another possibility was for the student to attend one more year and graduate in 5 years with both qualifications.

\section{The Origins of the Institution and Its Initial Phase (1961-1973)}

For Kaës (1997), the first phase of development of an institution is characterized by the getting together of individuals around a project that is present in an articulate form in the mind of its founder. Normally the latter perceives the anxieties that exist in the institutional scenario and transforms it into a project that carries special promise, facing the corresponding difficulties involved in its implementation. We can therefore understand that a demand of the area for professionals was met by people willing to tackle the problem. To start with, Prof. Paulo da Fonseca Guimarães summoned the person who would be considered the founder of the Institution: Prof. Waldemar Safiotti.

Based on the interviews, we find that the teachers are unanimous in highlighting the role of Professor Saffioti in the history of the course. He came from USP and took over as head of 
the Chemistry Department from 1961 to 1962 , and later from 1965 to 1967 . He was elected director of IQ after his retirement (1978), occupying the position from November 1984 to November 1988. Currently Prof. Saffioti is considered by the IQ community one of the main contributors to the establishment and maintenance of the course (Massabni et al., 1999, 2003) - there were times when we was the only professor of the whole course. Several statements point to the importance of Prof. Saffioti's role in defending the course, especially against the resistance put up by USP, and he considered the course in Araraquara "Saffioti's prep course." Albeit derogatory, this expression reinforces the importance of the figure of Prof. Saffioti to the institution.

For Kaës, articulated in the original moment is an initial phase of group formation, which has a unifying function, prescribing the proper ways to perform the task and building each member's identification with the group for the achievement of their wishes (shared narcissistic contract), as well as the mechanisms of defense against the dangers that may threaten the ongoing groupality (negational pacts). Apparently, we can see the relationship of the course with USP as a conditioner of the process: the members' dream of making the Institution "equal" to this reference would thus be the "narcissistic contract" of this group. We have already highlighted the distrust of USP regarding Araraquara, which probably led to the dream of recognition that was achieved gradually over time. The reference to USP is easily understood in the context of analysis of the scientific and academic field, as proposed by Bourdieu (1983b). For him, the field is a structured space of unequal positions of the dominant and dominated and a place of struggle for the monopoly of legitimate violence (specific authority), starting from specific objects of contention and interests irreducible to other fields. In the scientific field, dispute occurs through scientific authority, i.e., "a particular kind of social capital that ensures power over the field's constitutive mechanisms and that can be converted into other kinds of capital" (Bourdieu, 1983b, p. 130). Thus, in this analysis it is clear that USP occupies the place of the dominant, according to Bourdieu, those that impose a definition of science that consists of having, being and doing what they have, are and do. In this place, strategies of conservation are adopted that have already been illustrated, such as resistance against the creation of another Chemistry course in the state of São Paulo, by devaluating what the "newbies" would produce as science as an object of education and research. The dominated, in turn, would employ strategies of subversion, aiming initially to find a space of legitimacy in this field, and eventually occupying the place of the dominants. The difficulty of this dispute is aggravated because, in the scientific field, "only scientists engaged in the same game have the means to symbolically appropriate the body of scientific work and evaluate its merit" (p. 127); "there are no instances that legitimate the instances of legitimacy [...] insofar as the very definition of the criteria of judgment and principles of hierarchy are at stake in the struggle, no one is a good judge because there is no judge who is not a judge and also an interested party" (p. 130).

As for the group's defense mechanism against dangers that could threaten the construction of the Institution, the "negational pact" we can identify Prof. Waldemar Saffioti's "stubbornness" in disregarding the initial fears and failures and in never doubting the project. Apparently, in our case, this pact consisted of not fomenting USP's distrust about the course, in other words, 
of disregarding criticisms. We emphasize that the statements contain few explicit references to this distrust, and in general it will be expressed more clearly and directly by Professor Gastmans, who can be considered the "spokesman" of this group. In his testimony he highlights how difficult it was for the institution, "at the beginning, to be rejected by the only school of chemistry that existed in the state of Sao Paulo," revealing the weight of this mistrust which could not be considered for the sake of maintaining the course.

Kaës (1997) also notes the presence of "intermediaries" in all the stages of development of institutions; they will be responsible for adjusting the problems encountered to the possibilities of the group and for overcoming them, reconciling the conflicting elements. There were several challenges at the time the course was created, and for each of them we have identified potential intermediaries found by the institution. We believe that they are related more directly with the institutional habitus, revealing values and beliefs and promoting practices among the agents of the Institution, selected from a set of possible solutions.

\subsection{Challenges Faced and Intermediates Found}

The first challenge for the creation and maintenance of the course was hiring the teaching staff, according to the professors. In addition to its distance from the capital and the lack of resources of the new units, we can highlight the conditions of salary and of academic career as less favorable than those offered by USP, and also the boycotting by USP teachers, who discouraged their students from coming to teach in Araraquara. It is interesting to note that the other courses in Araraquara did not seem to suffer from a lack of professionals, indicating that hiring them was easy, and thus pointing to the lack of academic prestige of the area of Humanities - which is also mainly formed by women (Dias-da-Silva e Muzzeti, 2006). Furthermore, we can assume that, in view of the social hierarchy of the scientific fields analyzed by Bourdieu (1983b), exact sciences have greater autonomy vis-à-vis external influences, and therefore, greater social arbitration, which would be at the root of the higher valuation of this area.

Despite the challenges of hiring, one of the first solutions was the recruitment of foreign professors and of lecturers. Besides initial difficulties in persuasion, Saffioti managed to convince some of these teachers to "embrace his cause" and to stay on at the institution until he retired. Gastmans reveals that he remained in Brazil instead of returning to Belgium because of the spirit created around Saffioti, "in the end, maybe that's why I stayed; I think it's an esprit de corps that is created, and this remained": he appears to have joined the narcissistic contract.

A second solution, previously pointed out by Vaidergorn (1995), was the use of former students, or "homegrowns." The interviewees point out various aspects involved in the hiring of former students. For them, this use of former students had two main consequences for the history of the Institute. On the one hand, it compelled the students to become actively engaged in research work, which they did in the postgraduate program at USP or abroad, to avoid certain "eugenics" or "consanguinity." On the other hand, it ended up by reinforcing a sense of belonging, of attachment, of loyalty and commitment to the Institution which was 
very important in this period of its creation. Thus, these alumni were considered the main people responsible for the Institution's development and advancement in the area of research.

Another consequence of the small student body and teaching staff was that it forged a closer relationship between these groups. The teachers interviewed in our survey confirm the existence of this proximity and point out several reasons for it: the small number of students and faculty, the longer contact time, the monograph discipline, "simpler" teachers, an informal environment, transport conditions, and the characteristics of teaching and research in those times.

Resuming the discussion about the challenges of hiring, the two solutions presented can be considered "intermediaries." We believe they indicate a constitutive aspect of the institutional habitus, which can be perceived in the teachers' reports: a very strong feeling of belonging and of connection to the Institution. Most of the interviewees confirmed this impression and attributed this bond to the fact that they participated in the creation and consolidation of IQ. These discourses are marked by references to paternity and family.

The initial working conditions favored a closer relationship between teachers and students, as mentioned earlier, while at the same time focusing everyone's attention on education, since the conditions required for doing research were absent. A differential in the Chemistry course was the requirement of submitting a course conclusion monograph for both the Bachelor's and Licentiate degrees in Chemistry. "The Chemistry course in Araraquara is a pioneering one in the state of São Paulo in implementing a monograph requirement (science introduction) as a compulsory subject in the curricular content of the course" (Furlan et al., 2008, p. 23). In addition to improving the educational level, this measure was strong incentive for the development of research in the Department of Chemistry.

The "intermediary" found by the Institution to confer quality and differentiation to the education of professionals was research; albeit incipient, it seems to have provided the conditions needed for the course to offer quality education to ensure competitiveness in the market. The strong link to research seems to be a striking disposition of the institutional habitus, since it provided the conditions needed to support the "narcissistic contract."

The teachers describe several other challenges experienced at the beginning of the course, most of them involving the need for laboratories for the chemistry course. These difficulties appear to be related with the widespread complaints about the distribution of funds in FPSLA. According to the teachers' statements, funds intended for Chemistry were often diverted and appropriated by other departments with majority seats on the Board of the Faculty. This faculty initially operated in the same building at the city center. The teachers describe accidents that occurred in this location and the inconvenience for the other courses, such as the production of strong odors during laboratory practice. The solution to minimize departmental infighting and improve the physical conditions for the development of the course was to transfer the Chemistry course to a lot away from the city center, with poor conditions of transportation and pavement. The building was designed to house the permanent premises of the Department of Chemistry of FPSLA, with a physical area of 2790 square meters. The Department's transfer was completed by 1964, thus enabling the 
beginning of research in the laboratories, and they never share the same space with the rest of FPSLA (Furlan et al., 2008).

According to our interpretation, the establishment of the Department represents the final milestone in the process of the Institution's foundation. For Kaës (1997), a second phase of the institutionalization process begins with the emergence of new demands and new tasks and commitments developed by the group itself: it is the ideological moment with the placement of a group envelope, with the announcement of the first common rules that should facilitate the realization of the group's task. In this phase, a specific tension enters the scene: the inclusion of the similar and possibility of excluding the different. In our case, not only the members consider themselves independent from the Faculty and want to show this publicly, but also the Faculty recognizes this effective autonomy, based mainly on the different organization of the academic activities, linked to the dominant role of the research and didactic laboratories, which are unknown in other departments. We can see that the intermediary found to solve the challenge of building an autonomous institution points to a movement of progressive isolation of the course, along with the search for excellence in the performance of its activities, which are attitudes that appear to be constitutive of the institutional habitus. Thus, at other moments in the Institution's history, this intermediary will be revived by the agents, contributing to the maintenance of this framework.

\section{The Institutionalization of the Institution (1974 to 1990)}

In this phase the intermediates found previously - research, autonomy and unity among the group members - were revived, reinforcing its role of solving the Institution's problems, as well as strengthening the institutional habitus constituted earlier. This movement of revival can also be understood based on the field concept, because, according to Bourdieu (1983b, p. 91) "the whole history of the game, the entire past of the game, are present in every act of the game."

The process of institutionalization of the Institution was supported upon two distinct elements: recognition of the quality of the course and of the research on the part of USP; a concrete process of autonomy promoted in the context of creation of UNESP. The first element was based on a strong effort from the professors to publish more than USP, which was achieved and reflected in financial support from a São Paulo research funding agency. At the same time, the testimony of Professor Luis Antonio Andrade de Oliveira and other teachers points to the recognition of the quality of education, through the approval of students graduating from this Institution in the selection process for postgraduate courses at USP.

The second element was based on the austere political moment imposed by the military dictatorship (1964-1985) experienced during this phase, that brings the need for greater control over the independent institutes of higher education. A proposal was put forward to join all the Liesesps and create the Universidade Estadual Paulista "Julio de Mesquita Filho" - UNESP [São Paulo State University]. In 1974, the Department had sent a petition to the Governor of the State of São Paulo containing the signatures of 127 faculty members, staff and students asking that the Department of Chemistry of FPSLA be transformed into the Institute of Chemistry (Furlan et al., 2008). Albeit traumatic in some ways, the creation of 


\section{MInstitute Macroth $^{m}$}

UNESP favored the creation of the Institute of Chemistry, described in its final format in the constitution of UNESP, by updating the intermediary associated with the group's autonomy. This request by the group reveals the main characteristic of the second phase of development of an Institution: the phase of unification and establishment of a relationship among peers, leading to the exclusion of the different. Based on the theoretical framework of Kaës, we can identify two versions of distinction between those outside and inside the group: the ideological version consists of the exclusion of elements outside the group, while the transitional version consists of a less rigid and more tolerant accomplishment of this separation which does not necessarily lead to exclusion. At the time UNESP was created, proposals were also put forward for the creation of the Licentiate courses in Chemical Sciences and Engineering. We note that the ideological version applied to Engineering, whose proposal, until 2013 has not been realized, while the Licentiate course underwent a transitional version, i.e., it was implemented, then canceled, and finally adopted definitively.

The relationship with the Licentiate course underwent alternating experiences depending on the Institution's interests and external demands and regulations. Initially, the course was offered in conjunction with the bachelor modality until 1975, when a change in the Federal Board of Education, which established the obligatoriness of offering Full Licentiation ${ }^{2}$ in Science with a major in Chemistry, ended the possibility of offering the Licentiation in Chemistry until 1978.

In fact, the IQ had to implement full and abridged Licentiation in Sciences by federal mandate, but this course was fully in tune with the Institution's philosophy, which valued an excellent and disciplinary scientific education. That is why the Licentiate course in Sciences was abandoned, even though the request for conversion was approved. However, this solution was unsatisfactory. According to the statement of the employee Neusa Maria Luiz, who served for many years in the area of academic administration, the IQ was interested in offering the Licentiate course and the solution found by the Dean was to reactivate the offer of the Licentiateship in Sciences with Full Specific Qualifications in Chemistry. From 1986 on (UNESP Resolution 17/86), bachelor students could, by taking advantage of studies, request a Licentiate degree in Sciences with full qualifications in Chemistry; however, this alternative also was deactivated in 1990.

These comings and goings, the activation and deactivation of the Licentiate course in Sciences, reveal the ambiguity of the Institution, which in fact understood the loss represented by the absence of the Licentiate course, but was not satisfied with the solution proposed by the Dean's office. Perhaps this ambiguity is understandable in light of the "obligation" incurred by the institution upon its foundation, since the education of Chemistry professors was one of the basic justifications for the course.

After the definitive establishment at the new location, the Department's main concern, based on the Institute's strong vocation for research, was to enter the national postgraduate circuit. This had already been regulated in Brazil and the courses started in 1970, mainly at the most

\footnotetext{
2 In Brazil, teacher education involves a full licentiate course, and in addition there is an abridged licentiate course, which is shorter, that qualifies teachers for elementary and child education.
} 
renowned Public Universities. Having their application for accreditation accepted by the National Postgraduate Council was a sign of recognition all the research institutes desired. That is why it became the Institution's primary goal. The accreditation of the Postgraduate Program in Chemistry was approved by the National Postgraduate Councill in 1978. Thus, the Institution was recognized nationally as an institution devoted to research, confirming its most fundamental characteristics. Over the years, other areas and lines of research were implemented in the program.

Our interpretation of events is that, with the gradual implementation of the various areas of Postgraduate courses, the process of institutionalization of the Institute of Chemistry of Araraquara was concluded, inasmuch as it has a stable and articulated internal structure and is recognized nationally and internationally as an institution that produces knowledge and research. Thus, the institution could feel satisfied with the position it has achieved, which is comparable to that of many other Brazilian institutions, or it could try to become singular by exploiting all its potentialities, i.e., articulating and organizing its resources and the initiatives of its members.

\section{The Phase of Maturity of the Institution (1991 to the Present)}

We define as the phase initial landmark the creation of the licentiateship in 1991, because it reveals the revision of aspects that were not previously addressed, as well as compliance with external demands. Simultaneously, the development of the postgraduate and community projects reveals processes that were only possible when the Institution reached its maturity. This development seems to have been planned by the Institution for the first time - again revealing its maturity - more systematically and lastingly than in the previous phases. Today the Institute is a major center for research, teaching and extension in Chemistry, attested to by its scientific output, agreements with large companies, and the reputation of its undergraduate and postgraduate courses. This growth is illustrated in Figure 1, which highlights the first building and its physical area is represented by a growth of about 30 -fold.

In its third phase of development, with a change in the a federal resolution in 1991, the Institution will accept the implementation of a night time Licentiate course in Chemistry and find a suitable structure, enabling it not to be seen as a threat to the institution's development, but instead, bringing it additional gains. According to some statement, the course catered largely to an external demand by offering night time courses, specially to supply the region's demands for professionals in the area. This profile was characteristic of the first classes but subsequently underwent changes.

In view of the IQ' history of strong tradition in research, which ensured it a space of legitimacy in the scientific field, the curriculum of the Licentiate course created in 1991 enables its graduates to work in industry, since the Regional Board of Chemistry gives it the same qualifications as those of the bachelor course. We see here an updating of the research disposition constitutive of the institutional habitus, which had already ensured the quality of the bachelor course and could ensure now the quality of the Licentiate course. 


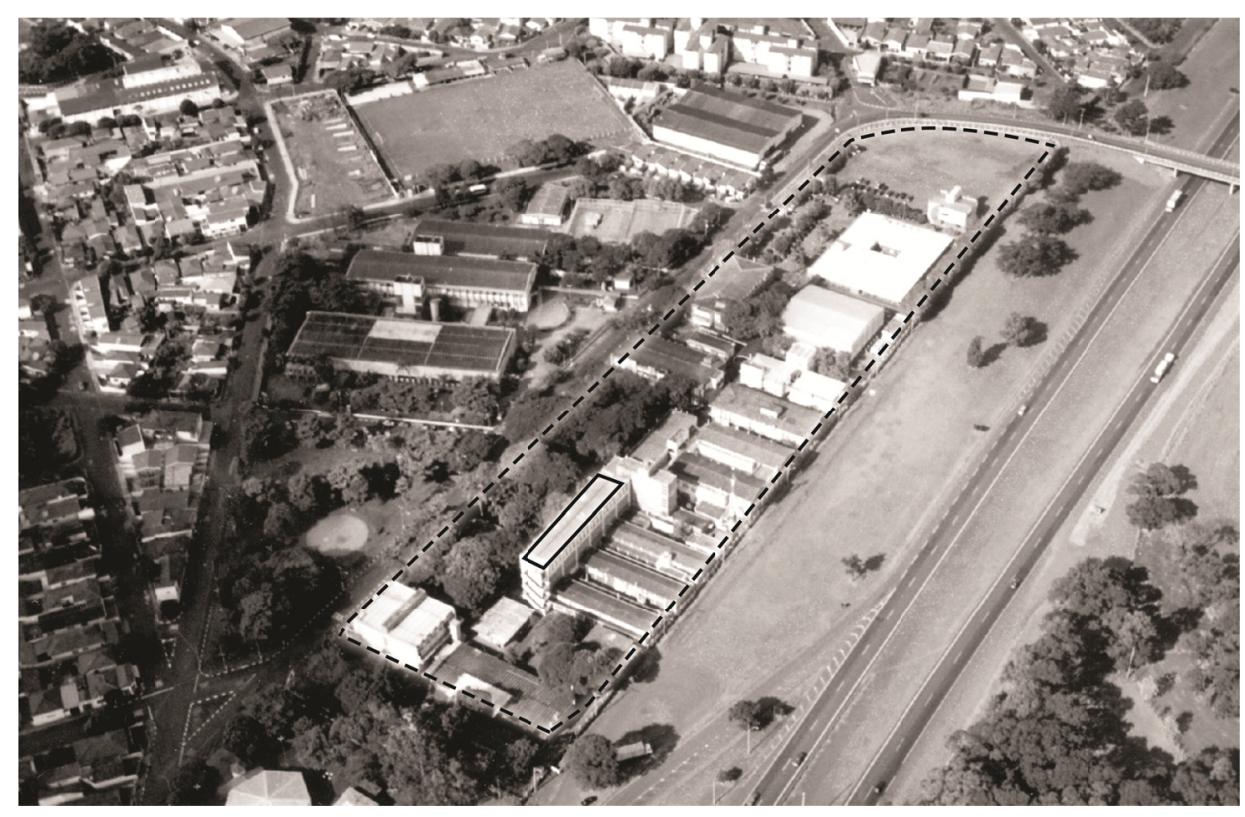

Figure 1. Aerial view of the Institute of Chemistry in 2011, the original building constructed in the $60 \mathrm{~s}$ is highlighted in a solid line rectangle and the actual area is highlighted in a dashed rectangle (Santos \& Luiz 2011)

We believe that the inconsistency observed between an initial goal of education and the development of the Institution originates from the education of the teachers at the beginning of the course, through a "snowball" process that influenced the referral of students to research and industry. But what strikes us is not the fact that the Institution devote itself to other teaching and research activities, but that the training for research and the bachelor modality are so much stronger symbolically than the Licentiation and the concern for teacher education. After this modality was suspended it was reinstated under a configuration that favors the inclusion of students in chemical research, in what appears to be a strategy of converting these students consistent with the institutional habitus and disposition for research.

Following the development of the postgraduate program, the areas of concentration were unified and a new Postgraduate Course was created in 1993 (Furlan et al., 2008). It was a painful but necessary process to achieve the highest ranking in the assessment of CAPES [Federal Agency for the Support and Improvement of Higher Education]. In this process we again observe the compliance with external demands and the revision of issues that had been "avoided" earlier, such as the exclusion of teaching staff from the postgraduate program, which was necessary to unify the program.

The unification of the postgraduate program was also evidence of a process of massification and quantification of scientific output that had already begun and that significantly increased the requirements for researchers and changed the type of research and collaboration. According to the teachers, this was presumably one of the main reasons why the previous almost family-like format of the IQ and the "esprit de corps" among the teaching staff was lost. This perception extends to the governing body, which, along with the teachers, saw a considerable increase in work requirements. It is also believed that there were negative 
consequences for the quality of undergraduate education. Thus, the research habitus collided directly with the old harmony and sense of belonging that were at the heart of the "esprit de corps" which also constituted the institutional habitus. On the other hand, the students and alumni still seem to nurture this feeling, according to our data and other bibliographic sources about the institution, which reveals a difference in the perception of that disposition on the part of the agents, as well as its reorganization by the teachers.

If research constitutes a constant intermediary throughout the history of IQ, the community program only gained space to develop fully starting in the phase of maturity of the Institution, where was already established and could meet external demands and revise issues that had previously been "avoided." In this case, there was a demand from the dean's office and later from the board of IQ for the institution to develop community projects, since UNESP regarded it as one of its strong points vis-à-vis other universities in the state that had better conditions for developing research. Moreover, by investing in extension, IQ could tackle a problem experienced since the course was created, concerning the scanty integration with the city of Araraquara, due to its history of politically motivated creation and because it catered to an audience mostly external to the city. Thus, a new intermediary emerges in this phase, community projects, which will become a disposition of the institutional habitus. We believe that the projects contributed to a marketing strategy of the Institution, which also seems to be constitutive of its habitus, i.e., the extension program would be linked directly to marketing. These aspects can be perceived by the constant concern of teachers and even students to publicize all the kinds of good results of the Institution, usually based on quantitative criteria. One of the reasons given for the use of strategies of communication and again of marketing is the increase in the applicant/vacancy ratio of the course, which would allow for a better selection of incoming students, i.e., a focus on the "client" or "target audience." This still seems to be a concern today, as we can see from the interviews held with teachers, in which the waiting lists mean that the placement of the last applicant is up to five times higher than the number of vacancies.

Notwithstanding this rationale, the development of community projects at IQ was considered complicated, because it was an academic unit whose main focus was research. Some extension projects already existed in the early 90s, and others were created during this period, making a total of 10 large projects that continue today. Among the Institution's various projects we can identify different "roles" they play in meeting students' and institutional needs. Initially we highlight the projects aimed directly at serving the community outside the institution and at publicizing the IQ, whose indirect result may be the recruitment of "future scientists" interested in the Chemistry course. Other projects appear to have emerged for the purpose of supporting undergraduate education in Chemistry, which contribute indirectly to publicize the Chemistry course in the community outside the IQ. Aiming at a broader and more comprehensive training of undergraduates, we find projects aimed at professional training for industry from the standpoint of laboratory experience. From the business standpoint, there are projects such as the Junior Chemistry Projects and Consulting, while for teacher training there is the Science Center of Araraquara. Some projects, like theater, focus 
on a diversified cultural education, which, according to students' statements, also serve as "escape valves" from the studies required for graduation.

In addition to undergraduate disciplines, participation in research and extension projects seems to play a major role in student education, through direct involvement in activities and through the training teachers receive in the classroom, allowing for a real link between the actions of teaching-research-extension. These new moments and contexts of education also provide opportunities for (re)socialization. The licentiate has advantages over the bachelor student with respect to participation in these projects, because he has the whole day free. The teachers' statements also reveal the importance and role of extension in education. On the one hand, the bachelor course is valued as the principal course while the licentiate is considered less prestigious, probably due to the different cultural backgrounds of the selected students. On the other hand, licentiate students seem more interested and available to attend the postgraduate course in Chemistry than bachelor students, who prefer the professional perspective of working in industry. Thus, for the Institution, the contribution of licentiate students is fundamental to the performance of the postgraduate program and to research.

Some of the students' statements go so far as to imply that extension projects compensate for deficiencies in training, such as the low performance of the Licentiation course in teacher education, in a context of strong valuation and investment in research. In this sense, some projects appear to oppose the institution's general trend of training the licentiate student for research and for industry, offering direct contact with the teaching practice and allowing for a more positive vision of this activity.

A symptom and consequence of the prospect of investment in extension was also the concern in reducing student dropout rates as much as possible by adopting various initiatives described in the literature (Brag et al., 1997; Machado et al., 2005) that could reduce the problem. These initiatives include a students receiving program held during the "Freshman Week"; a Calculus teaching program based on fundamental mathematics; a curriculum overhaul favoring the inclusion of students in extracurricular activities; the offer and management of scholarships; promotion of the profession of chemist and of the chemistry course among high school students through extension projects such as "Lectures at School;" participation in career fairs, and visits of these students to IQ, promoted by the Special Training Program.

As for the intermediary of autonomy which was instrumental in the first two phases, we find remnants of it in the third phase, as indicated by IQ's scanty integration with other units of UNESP Araraquara across the state, and with the chemistry courses at other universities of São Paulo. This hypothesis was confirmed by teachers who consider this type of interaction nonexistent in all the other courses. In Araraquara, integration apparently depends on the current boards of other the academic units, but the IQ's practices and the testimonies of students make little mention of situations of significant interaction. In relation to other UNESP units that gave chemistry courses, the initial tendency for rejection and scanty interaction is gradually diminishing thanks to the hiring of IQ alumni who maintain professional connections and friendships with their former advisors. Contacts are also 
established to discuss undergraduate curricula promoted by the Dean of UNESP; the proposal is not to establish a single curriculum but an ideal one that could serve as a model for all the chemistry courses. As regards the area of chemistry at the other universities in the state, interaction exists only at the postgraduate level through individual initiatives and research groups seeking to promote connections among universities.

This scanty interaction among other chemistry courses may be explained by physical distance, but we believe that the main reason is the historical origins of the creation of each university and course, as well as the positions and hierarchies of these universities in the academic field. Apparently the IQ managed to carve out a space of legitimacy in the field of research. The fact that it is a unit of UNESP represents an obstacle to achieving this position, given the administrative difficulties of a multi-campus university. Moreover, this university has less recognition and political strength than USP and UNICAMP. This leads to the impression that the IQ pays the price for being UNESP, even though it stands out in the university: it was one of the first postgraduate programs of UNESP and for many years was the unit that most raised funds from outside UNESP.

\section{Conclusions}

We can see along the Institution's history the presence of four constitutive dispositions of the institutional habitus: research, harmony among the members, autonomy and extension/marketing. Throughout the phases, these intermediaries and dispositions were updated to meet the demands of different times. Research was incipient during the first phase, but was seen as goal to ensure legitimacy and was achieved in the second phase, thanks to heavy investments in publishing and good placements of students in postgraduate selection processes. In the third phase research continues to represent a major investment by the Institution, which faces challenges because "it is UNESP" and lacks the organizational structure and social representativeness the other institutions enjoy. The harmony among its members was instrumental in the first phase of the institution to ensure its continuity in the face of numerous challenges; references to a "family" among the faculty and students are constant but appear to begin to fade starting in the second phase. In the third phase this disposition was converted to an ethical relationship among the teachers, but remained like family relationship for the students, albeit with less intensity. IQ's autonomy appeared in the first stage in physical form, through its separation from the FPSLA, and in the second phase in administrative from, through the creation of the IQ. In the third phase we still see remnants of this disposition through the scanty integration of IQ with other undergraduate courses in Chemistry at other institutions and at UNESP and with other UNESP courses in Araraquara, in contrast to a few individual interactions in terms of research. The extension/marketing disposition will emerge only in the third phase, consistent with a broader movement of neoliberal influence on education, in which the institution's concerns shift to management, publicizing results, and attracting new "clients." This disposition will bring, almost unconsciously for the institution, substantial gains for student education and low dropout rates, particularly among the licentiate students. 
In general, if our interpretation is correct, the maturity of the Institution was characterized by an expansion of the narcissistic contract and the negational pact. After achieving recognition for its excellence in research, the Institution's investments (or at least of its leading group) were directed at transforming it into an institute of reference in research, teaching, and extension. Thus, licentiate students could be recognized as important actors of the institution, not only for their contributions to research but also for their investments in extension or teaching. IQ/Araraquara thus differed from prestigious institutions that concentrated their investments in research and left little room for initiatives in other fields. It seems right to determine that the focus of these institutions is international recognition for the competitiveness of their researches, while the focus of IQ Araraquara is the status of the institution as a whole. This has allowed for an organized management of the pressures and initiatives of the Dean's Office, the board, teachers and students directed at the recognition of the Institution's excellence and at solving the problems it encounters, at least partially.

As evidence of this trend we can cite the institutional marketing effort to demonstrate that the institution is no longer the 'ugly duckling' but has become the swan among university institutions. Every student at the Institution is told that the library is the best in the country, that the dropout rate is minimal, and that the research groups that have the most modern equipment.

In this sense, we can also cite the memories of one of the authors concerning the period when she was an undergraduate student at the institution, when she recalls the prestige in informal discourses of teachers and students reserved for teachers dedicated to the administration of the institution and who insistently promoted its recognition. Instead, there were explicit criticisms of any teachers who were only concerned about the prestige of their own research groups.

To conclude, we emphasize a point that caught our attention: the institution's neglect of research in Science Teaching. There have been mostly only isolated initiatives, which were more limited than those conducted at other public institutions such as IQ-USP and IQ-UNICAMP, which included in their postgraduate programs the possibility of developing teaching-related projects. A possible explanation for this fact, which seems to contradict the whole process of expansion of the institutional objectives, may be, on the one hand, the fear of losing students who devoted their efforts to research in chemistry, and on the other hand, the historical relationship of conflict and competition with the Faculty of Philosophy, which favored the isolation of IQ. Perhaps the prejudice against the human sciences, considered 'the fluff' of teacher education, has generated mistrust in research in Science Education. However, according to our interpretation, there would be space for the development of research groups in this area within the institution in view of its multi-faceted character and its organizational capacity from the standpoint of institutional development. It seems to us that the development of research in Science Teaching does not meet the Institution's goals or its history. Instead, it would represent another way to serve the interests of teachers and students concerned about the area, as well as a way to offer students the same research opportunities as those offered by other Institutes of Chemistry of public universities, whose area of Science Education has long been under development. 


\section{References}

Bourdieu, P. (1983a). Esboço de uma teoria da prática (pp. 46-81). Pierre Bourdieu: Sociologia. R. Ortiz. São Paulo, Ática.

Bourdieu, P. (1983b). O campo científico (pp. 122-155). Pierre Bourdieu: Sociologia. R. Ortiz. São Paulo, Atica.

Braga, M. M., Miranda-Pinto, C. O. D., \& Cardeal, Z. D. L. (1997). Perfil sócio-econômico dos alunos, repetência e evasão no curso de química da UFMG. Química Nova, 20(4): 438-444. http://dx.doi.org/10.1590/S0100-40421997000400017

Corrêa, A. M. M. (2006). UNESP 30 anos: memória e perspectivas. São Paulo, Editora UNESP.

Dias-da, M. H. G. F., \& Muzzeti, L. R. (2006). Licenciaturas Light: resultado das lutas concorrenciais no campo universitário? Contexto e Educação, 75, 11-28.

Furlan, M., Luiz, N. M., \& Oliveira, O. M. M. F. (2008). Origem do Instituto de Química da UNESP registro histórico: evolução, consolidação e projeção. Araraquara, Instituto de Química, Universidade Estadual Paulista.

Kaës, R. (1997). O Grupo e o Sujeito do Grupo. Elementos para uma teoria Psicanalítica do Grupo. São Paulo, Casa do Psicólogo.

Lahire, B. (2002). Reprodução ou prolongamentos críticos? Educação \& Sociedade, 23(78), 37-55. http://dx.doi.org/10.1590/S0101-73302002000200004

Machado, S. P., Melo Filho, J. M., \& Pinto, A. C. (2005). A evasão nos cursos de graduação de química: uma experiência de sucesso feita no Instituto de Química da Universidade Federal do Rio de Janeiro para diminuir a evasão. Química Nova, 28(Suplemento), S41-S43.

Massabni, A. C., J. R. Ernandes and C. B. Melios (2003). Quatro décadas de Química na UNESP/Araraquara. Química Nova, 26(3), 439-444. http://dx.doi.org/10.1590/S0100-40422003000300024

Massabni, A. C., Melios, C. B., \& Franco, D. W. (1999). In memorian: Waldemar Saffioti. Química Nova, 22(4), 630-631. http://dx.doi.org/10.1590/S0100-40421999000400024

Reay, D., David, M., \& Ball, S. (2001). Making a difference?: Institutional habituses and higher education choice. Sociological Research Online, 5(4). http://dx.doi.org/10.5153/sro.548

Santos, T. J. A. d., \& Luiz, N. M. (2011). Intrepidez e determinação marcam história Araraquara, Instituto de Química, Universidade Estadual Paulista.

Thomas, L. (2002). Student retention in higher education: the role of institutional habitus. Journal of Education Policy, 17(4), 423-442. http://dx.doi.org/10.1080/02680930210140257

Vaidergorn, J. (1995). As seis irmãs: as Faculdades de Filosofia, Ciências e Letras - Institutos Isolados de Ensino Superior do Estado de São Paulo - 1957-1964. Alguns subsídios 


\section{Macrothink}

interpretativos para o estudo do Ensino Superior do Estado de São Paulo, Universidade Estadual de Campinas.

\section{Copyright Disclaimer}

Copyright reserved by the authors.

This article is an open-access article distributed under the terms and conditions of the Creative Commons Attribution license (http://creativecommons.org/licenses/by/3.0/). 